\title{
Composition of the Essential Oils of Juniperus oxycedrus $L$. subsp. oxycedrus Growing in Turkey
}

\author{
Türkiye'de Yetișen Juniperus oxycedrus L. subsp. oxycedrus'un \\ Uçucu Yağ Bileșikleri
}

\author{
Sevim ALAN1, Mine KÜRKÇÜOĞLU2, Görkem ŞENER¹,2 \\ 1Anadolu University, Faculty of Pharmacy, Pharmaceutical Botany, 26470 Eskișehir, TURKEY \\ 2Anadolu University, Faculty of Pharmacy, Department of Pharmacognosy, 26470 Eskișehir, TURKEY
}

\begin{abstract}
In this study, the chemical compositions of the leaves, berries and twigs essential oils of J. oxycedrus L. subsp. oxycedrus, collected in Turkey, were determined. The oils were analyzed by GC and GC-MS. 15-21 volatile compounds were identified of the leaves, berries and twigs essential oils representing $82.4-98.0 \%$ of the total oils. The essential oils were obtained from leaves, berries and twigs by yielding $0.02 \%, 2.12 \%$ and $0.01 \%$, resp. The major compounds were determined manoyl oxide (32.8\%) and caryophyllene oxide (11.9\%) in leaf oil, myrcene (44.6\%), a-pinene (19.9\%) and germacrene D (15.5\%) in berry oil, manoyl oxide (35.4\%) and caryophyllene oxide (16.8\%) in twig oil.

Key words: Juniperus oxycedrus, GC and GC/MS, Essential oil

Öz

Bu çalıșmada, Türkiye'den toplanan J. oxycedrus subsp. oxycedrus türünün yaprak, meyve ve ince dallarından elde edilen uçucu yağlarının kimyasal içerikleri belirlenmiştir. Uçucu yağlar GC ve GC/MS cihazları aracılığıyla analiz edilip, toplam yağın \%82.4-98.0 içeriği 15-21 arasında değişen uçucu bileşen ile yaprak, meyve ve ince dal üzerinde tespit edilmiştir. Uçucu yağlar yaprak, meyve ve ince daldan sırasıyla \%0.02, \%2.12 ve $\% 0.01$ verimleri ile elde edilmiștir. Ana bileșenler yaprak yağında \%32.8 manoil oksit ve \%11.9 karyofillen oksit, meyve yağında \%44.6 mirsen, \%19.9 a-pinen ve \%15.5 germakren D, ince dal yağında \%35.4 manoil oksit ve \%16.8 karyofillen oksit belirlenmiștir.
\end{abstract}

Anahtar kelimeler: Juniperus oxycedrus, GC and GC/MS, Uçucu Yağ

\section{INTRODUCTION}

The genus Juniperus L. belongs to the Cupressaceae family, representing about 70 species all over the world, and widely distributed throughout the forests of the temperate and cold regions of the northern Hemisphere, from the far north to the Mediterranean. Juniperus L. is represented in Turkey by 7 species and 14 taxa. Juniperus oxycedrus has two subspecies - subsp. oxycedrus and subsp. macrocarpa - in Turkey (1,2).

Several studies have reported the chemical composition of leaves, berries and twigs and their the essential oils (EOs) of J. oxycedrus L. subsp. oxycedrus (Table 1) (3-16).

In the present work, leaves, berries and twigs EOs of $J$. oxycedrus subsp. oxycedrus were investigated to chemical compositions of plants collected from Eskişehir: Hekimdağ in Turkey. In the study, the oils were obtained by hydrodistillation.
The oils were analyzed by gas chromatography (GC) and gas chromatography/ mass spectrometry (GC/MS).

\section{EXPERIMENTAL}

\section{Plant material}

J. oxycedrus subsp. oxycedrus was collected from Eskişehir: Hekimdağ, in Turkey on 15 March 2015. Voucher specimens are kept at the Herbarium of Pharmacy Faculty, Anadolu University, Turkey (ESSE 14987).

\section{Isolation of essential oils}

The oils were obtained by hydrodistillation for 3 hours using Clevenger apparatus. The essential oils were stored at $4^{\circ} \mathrm{C}$ in the dark until analyzed. The oils were analyzed by capillary GC and GC/MS using a Agillent GC-MSD system. 
Table 1. EO yield and chemical composition of Juniperus oxycedrus L. subsp. oxycedrus (3-16)

\begin{tabular}{|c|c|c|c|}
\hline Part of plant & Yield \% & Major compounds \% & Ref. \\
\hline Leaf & $\begin{array}{l}0.7 \\
H D\end{array}$ & $\begin{array}{l}\alpha \text {-Pinene }(42.9 \%) \\
\text { Limonene }(17.8 \%) \\
\text { Caryophyllene oxide }(5.1 \%) \\
\beta \text {-Myrcene }(3.9 \%) \\
\beta \text {-Pinene }(3.8 \%)\end{array}$ & 3 \\
\hline Leaf & $\begin{array}{l}0.01 \\
H D\end{array}$ & $\begin{array}{l}\text { a-Pinene }(17.1 \%) \\
\text { 13-epi-Manoyl oxide (12.5\%) } \\
\text { (Z)-6-pentadecen-2-one (11.5\%) }\end{array}$ & 4 \\
\hline Leaf & $\begin{array}{l}0.1 \\
H D\end{array}$ & $\begin{array}{l}\text { trans-Pinocarveol }(7.0 \%) \\
\text { cis-Verbenol }(6.3 \%) \\
\text { Manoyl oxide }(6.0 \%)\end{array}$ & 5 \\
\hline Leaf & $\begin{array}{l}1.66 \\
\mathrm{HD}\end{array}$ & $\begin{array}{l}\text { a-Pinene }(31.25 \%) \\
\text { Sabinene }(5.21 \%) \\
\text { Limonene }(5.02 \%)\end{array}$ & 6 \\
\hline Leaf & $\begin{array}{l}0.2 \\
H D\end{array}$ & $\begin{array}{l}\text { Limonene }(30.0 \%) \\
\text { a-Pinene }(26.3 \%) \\
(Z, E)-\text { Farnesol (5.1\%) } \\
\text { Salvial-4 (14)-en-1-one (4.9\%) }\end{array}$ & 7 \\
\hline Leaf & $\begin{array}{l}0.4 \pm 0.14 \\
H D\end{array}$ & $\begin{array}{l}\text { a-Pinene (49.46\%) } \\
\text { Germacrene D (8.96\%) } \\
\text { 13-epi-Manoyl oxide (3.62\%) }\end{array}$ & 8 \\
\hline Leaf & $\begin{array}{l}0.2-0.5 \\
H D\end{array}$ & $\begin{array}{l}a-P \text {-Pinene }(41.3 \%) \\
a-P h e l l a n d r e n e(8.2 \%) \\
\text { p-Cymene }(6.2 \%) \\
\text { Manoyl oxide }(5.3 \%)\end{array}$ & 9 \\
\hline Berry & SPME & $\begin{array}{l}\alpha \text {-Pinene }(88.44 \%) \\
\beta \text {-Myrcene }(6.71 \%) \\
\beta \text {-Pinene }(2.07 \%)\end{array}$ & 10 \\
\hline Berry & $\begin{array}{l}0.97 \\
\mathrm{HD}\end{array}$ & $\begin{array}{l}\text { a-Myrcene (23.4\%) } \\
\alpha \text {-Pinene }(16.7 \%) \\
\text { Citronellol }(16.3 \%) \\
\beta \text {-Caryophyllene }(6.3 \%)\end{array}$ & 11 \\
\hline Berry & $\begin{array}{l}2.21 \\
H D\end{array}$ & $\begin{array}{l}\text { Citronellol (26.8\%) } \\
\text { a-Myrcene }(24.3 \%) \\
\text { a-Pinene }(14.4 \%) \\
\text { Limonene }(9.3 \%)\end{array}$ & 11 \\
\hline Berry & $\begin{array}{l}0.7-1.2 \\
\text { HD }\end{array}$ & $\begin{array}{l}\beta \text {-Myrcene }(56.87 \pm 4.6 \%) \\
\alpha-P i n e n e(14.84 \pm 2.9 \%) \\
\text { DL-Limonene }(5.96 \pm 0.6 \%)\end{array}$ & 12 \\
\hline Berry & $\begin{array}{l}0.4-0.7 \\
H D\end{array}$ & $\begin{array}{l}\beta \text {-Myrcene }(54.06 \pm 6.1 \%) \\
\alpha \text {-Pinene }(10.22 \pm 2.7 \%) \\
\text { DL-Limonene }(9.20 \pm 1.7 \%) \\
\text { Germacrene D }(8.56 \pm 1.7 \%) \\
(E)-\text { Nerolidol }(5.94 \pm 1.6 \%)\end{array}$ & 12 \\
\hline Berry & $\begin{array}{l}0.8-1.5 \\
H D\end{array}$ & $\begin{array}{l}\beta \text {-Myrcene }(49.75 \pm 3.8 \%) \\
\text { a-Pinene }(16.50 \pm 2.3 \%) \\
\text { DL-limonene }(13.82 \pm 2.7 \%)\end{array}$ & 12 \\
\hline Berry & $\begin{array}{l}0.9-1.5 \\
H D\end{array}$ & $\begin{array}{l}\beta \text {-Myrcene }(56.97 \pm 3.7 \%) \\
\alpha \text {-Pinene }(19.55 \pm 3.7 \%) \\
\alpha \text {-Cadinol }(3.92 \pm 1.6 \%) \\
\text { Germacrene D }(3.74 \pm 0.2 \%)\end{array}$ & 12 \\
\hline
\end{tabular}

\section{Table 1 continued}

\begin{tabular}{|c|c|c|c|}
\hline Berry & $\begin{array}{l}1.2-1.8 \\
H D\end{array}$ & $\begin{array}{l}\beta \text {-Myrcene }(45.50 \pm 3.0 \%) \\
\alpha \text {-Pinene }(36.64 \pm 2.0 \%) \\
\text { DL-Limonene }(5.75 \pm 2.1 \%) \\
\text { Germacrene D }(3.65 \pm 0.6 \%)\end{array}$ & 12 \\
\hline Berry & $\begin{array}{l}0.72 \\
\mathrm{HD}\end{array}$ & $\begin{array}{l}\alpha \text {-Pinene (27.4\%) } \\
\beta \text {-Myrcene (18.9\%) } \\
\alpha \text {-Phellandrene (7.1\%) } \\
\text { Limonene (6.7\%) }\end{array}$ & 13 \\
\hline Berry & $\begin{array}{l}2.5 \\
\mathrm{HD}\end{array}$ & $\begin{array}{l}\alpha \text {-Pinene }(27.4 \%) \\
\beta \text {-Myrcene }(18.9 \%)\end{array}$ & 14 \\
\hline Berry & $\begin{array}{l}0.5 \\
\mathrm{HD}\end{array}$ & $\begin{array}{l}\alpha \text {-Pinene }(60.60 \pm 3.33 \%) \\
\beta \text {-Myrcene }(24.97 \pm 1.76 \%) \\
\gamma \text {-Muurolene }(5.19 \%)\end{array}$ & 15 \\
\hline Berry & $\begin{array}{l}0.45 \\
\text { SFE }\end{array}$ & $\begin{array}{l}\text { Germacrene D (13.8\%) } \\
\alpha \text {-Pinene (10.5\%) } \\
\beta \text {-Myrcene ( } 8.1 \%)\end{array}$ & 16 \\
\hline Needles & 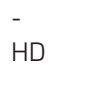 & $\begin{array}{l}\alpha \text {-Pinene }(92.22 \%) \\
\beta \text {-Myrcene }(2.46 \%) \\
\beta \text {-Pinene }(1.79 \%)\end{array}$ & 10 \\
\hline Wood & $\begin{array}{l}0.68 \\
H D\end{array}$ & $\begin{array}{l}\delta \text {-Cadinene (14.5\%) } \\
\text { cis-Thujopsene (9.2\%) } \\
\text { a-Muurolene (4.9\%) } \\
\text { Cadalene (3.7\%) } \\
\text { Eremophilene (2.5\%) } \\
\alpha \text {-Cedrol }(2.2 \%)\end{array}$ & 13 \\
\hline
\end{tabular}

HD: Hidrodistillation, SFE: Supercritical carbon dioxide extraction, SPME: Solid Phase Micro Extraction

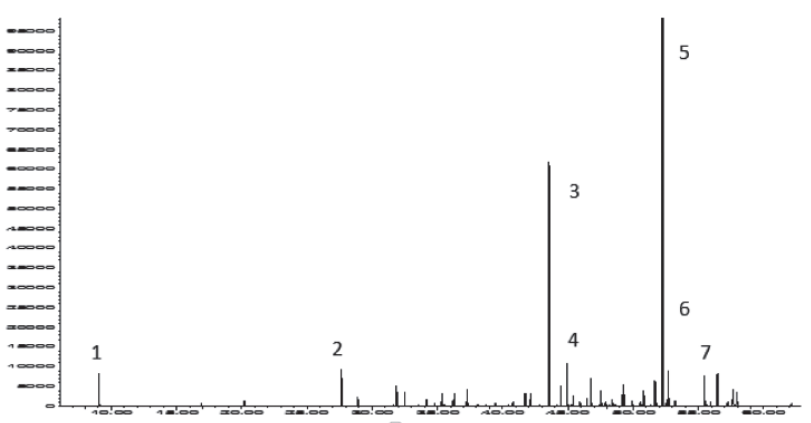

Figure 1. Chromatogram of the twigs essential oil of J. oxycedrus $L$. subsp. oxycedrus

1. $a$ - Pinene, 2. $a$ - Cubebene, 3. Caryophyllene oxide, 4. Humulene epoxide-II, 5. Manoyl oxide, 6. Caryophyllenol II, 7. Dodecanoic acid

\section{Gas Chromatography (GC) and Gas Chromatography - Mass Spectrometry (GC/MS) analysis}

The GC/MS analysis was carried out with an Agilent 5975 GC-MSD system. Innowax FSC column $(60 \mathrm{~m} \times 0.25 \mathrm{~mm}$, $0.25 \mathrm{~mm}$ film thickness) was used with helium as carrier gas (0.8 $\mathrm{mL} / \mathrm{min})$. GC oven temperature was kept at $60^{\circ} \mathrm{C}$ for 10 minutes and programmed to $220^{\circ} \mathrm{C}$ at a rate of $4^{\circ} \mathrm{C} / \mathrm{min}$, and 
kept constant at $220^{\circ} \mathrm{C}$ for 10 minutes and then programmed to $240^{\circ} \mathrm{C}$ at a rate of $1^{\circ} \mathrm{C} /$ minutes. Split ratio was adjusted 40:1. The injector temperature was at $250^{\circ} \mathrm{C}$. MS were taken at 70 $\mathrm{eV}$. Mass range was from $\mathrm{m} / \mathrm{z} 35$ to 450 .

\section{Table 2. Composition of the EOs of Juniperus oxycedrus L.} subsp. oxycedrus

\begin{tabular}{|c|c|c|c|c|}
\hline RRI & Compounds & $\begin{array}{l}\text { Twigs } \\
\%\end{array}$ & $\begin{array}{l}\text { Berries } \\
\%\end{array}$ & $\begin{array}{l}\text { Leaves } \\
\%\end{array}$ \\
\hline 1032 & a-Pinene & 2.4 & 19.9 & 1.4 \\
\hline 1132 & Sabinene & - & 1.4 & - \\
\hline 1174 & Myrcene & - & 44.6 & - \\
\hline 1190 & Sylvestrene & 0.7 & - & - \\
\hline 1203 & Limonene & - & 2.7 & - \\
\hline 1213 & 1,8-Cineole & - & - & - \\
\hline 1218 & $\beta$-Phellandrene & - & 0.7 & - \\
\hline 1280 & $p$-Cymene & 0.5 & - & - \\
\hline 1290 & Terpinolene & - & 0.5 & - \\
\hline 1466 & $\alpha$-Cubebene & 2.0 & 0.3 & - \\
\hline 1604 & Isobornyl acetate & 1.6 & 0.3 & 1.2 \\
\hline 1612 & $\beta$-Caryophyllene & 1.5 & 4.6 & 3.7 \\
\hline 1668 & $(Z)-\beta$-Farnesene & - & 0.5 & - \\
\hline 1687 & $\alpha$-Humulene & - & 3.1 & - \\
\hline 1704 & $g$-Muurolene & - & 0.3 & - \\
\hline 1706 & a-Terpineol & 1.9 & - & - \\
\hline 1726 & Germacrene D & - & 15.5 & 5.7 \\
\hline 1740 & a-Muurolene & 1.3 & 0.7 & 3.2 \\
\hline 1773 & $d$-Cadinene & 1.4 & 1.8 & 4.1 \\
\hline 1776 & $g$-Cadinene & - & - & 1.6 \\
\hline 1941 & $\alpha$-Calacorene & 0.7 & - & 1.8 \\
\hline 2008 & Caryophyllene oxide & 16.8 & - & 11.9 \\
\hline 2050 & (E)-Nerolidol & 1.4 & - & - \\
\hline 2071 & Humulene epoxide-II & 3.4 & - & 4.7 \\
\hline 2148 & Cedrol & 2.9 & - & - \\
\hline 2243 & Torilenol & 1.2 & - & 2.5 \\
\hline 2255 & a-Cadinol & - & 1.1 & - \\
\hline 2256 & Cadalene & 2.8 & - & 2.2 \\
\hline 2316 & Caryophylladienol I & 1.8 & - & - \\
\hline 2376 & Manoyl oxide & 35.4 & - & 32.8 \\
\hline 2392 & $\begin{array}{l}\text { Caryophyllenol II (=Caryophylla- } \\
2(12), 6 \text {-dien-5b-ol) }\end{array}$ & 4.5 & - & - \\
\hline 2503 & Dodecanoic acid (=lauric acid) & 4.2 & - & 3.1 \\
\hline 2524 & Abietatriene & 2.5 & - & 2.5 \\
\hline
\end{tabular}

RRI: Relative Retention Indices calculated against n-alkanes
The GC analysis was carried out using an Agilent 6890 N GC system. In order to obtain the same elution order with GC/MS, simultaneous injection was done by using the same column and appropriate operational conditions. FID temperature was $300^{\circ} \mathrm{C}$.

\section{Identification of compounds}

The components of essential oils were identified by comparison of their mass spectra with those in the Baser Library of Essential Oil Constituents, Wiley GC/MS Library, Adams Library, MassFinder Library and confirmed by comparison of their retention indices. Alkanes were used as reference points in the calculation of relative retention indices (RRI). Relative percentage amounts of the separated compounds were calculated from FID chromatograms.

\section{RESULTS AND DISCUSSION}

The EOs were obtained from leaves, berries and twigs by yielding $0.02 \%, 2.12 \%$ and $0.01 \%$, respectively. The list of compounds identified in the hydrodistilled leaves, berries and twigs of J. oxycedrus L. subsp. oxycedrus with their relative percentages and retention indices are given in Table 2.

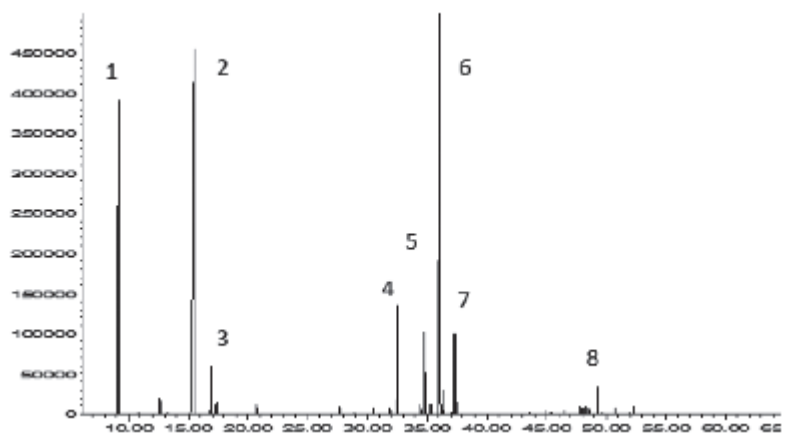

Figure 2. Chromatogram of the berries essential oil of J. oxycedrus $L$. subsp. oxycedrus

1. $\alpha$ - Pinene, 2. Myrcene, 3. Limonene, 4. $\beta$-Caryophyllene, 5. $\alpha$ - Humulene, 6. Germacrene D, 7. d-Cadinene, 8. $\alpha$-Cadinol

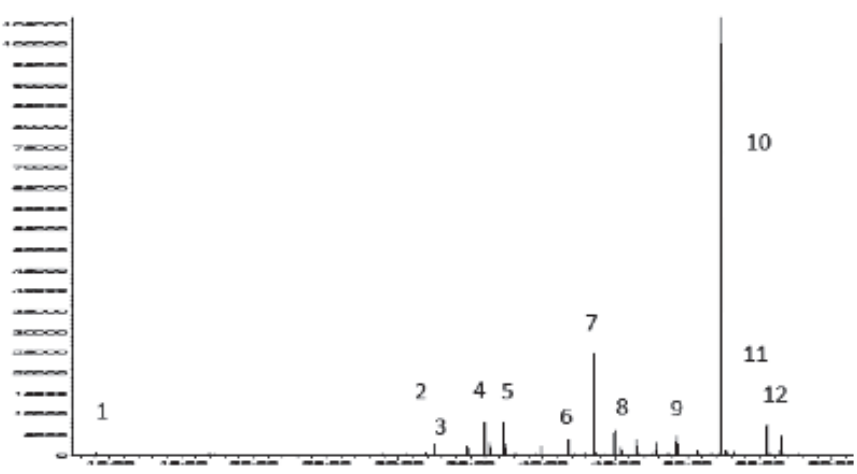

Figure 3. Chromatogram of the leaves essential oil of $\mathrm{J}$. oxycedrus $\mathrm{L}$. subsp. oxycedrus

1. $\alpha$ - Pinene, 2. Bornyl acetate, 3. $\beta$-Caryophyllene, 4. Germacrene D, 5. dCadinene, 6. $\alpha$-Calacorene, 7. Caryophyllene oxide, 8. Humulene epoxideII , 9. Cadalene, 10. Manoyl oxide, 11. Dodecanoic acid, 12. Abietatriene 
In our study, 15-21 volatile compounds were identified of the leaves, berries and twigs EOs representing 82.4-98.0\% of the total oils. Twig oil composition was not found in previous studies. Manoyl oxide (35.4\%) and caryophyllene oxide (16.8\%) were identified as major contituents in twig oil (Figure 1), myrcene (44.6\%), a-pinene (19.9\%) and germacrene D (15.5\%) in berry oil (Figure 2 ), manoyl oxide $(32.8 \%)$ and caryophyllene oxide (11.9\%) in leaf oil (Figure 3).

As seen in previous studies Table 1, the leaf oils were characterized by the presence of a-pinene, $t$-pinocarveol and limonene as main contituents (3-10). But, in our study, the occurrence of manoyl oxide and caryophyllene oxide was interesting. While some contituents like $\alpha$-pinene and myrcene were found in berry oil samples (11-15), germacrene D was only in one sample (16).

Medini et al. have reported $\alpha$-pinene, germacrene $\mathrm{D}$, myrcene, abietadiene and cis-calamenene as main constituents of the EOs of the berries of Juniperus oxycedrus L. subsp. rufescens (L.K.) and Juniperus oxycedrus L. subsp. macrocarpa (S. \& M.) Ball. (17).

Sezik et al. have reported manoyl oxide (21.9\%) and $\alpha$-pinene (11.3\%) as main constituents in leaf oil of J. oxycedrus subsp. macrocarpa from Eskişehir (18).

Variability of the oil composition in different populations of the same plant species might be attributed mainly to genetic diversity (19). Chemical composition and the main components of EOs J. oxycedrus have differentiate chemotype due to containing different climatic conditions of a large geographical diversity.

\section{ACKNOWLEDGEMENTS}

The author is grateful to Prof. Dr. K.H.C. Başer for allowing us to use the Bașer Library of Essential Oil Constituents during the GC/MS Analyses.

\section{REFERENCES}

1. Coode MJE, Cullen J, Juniperus L.; P. H. Davis, Flora of Turkey and the East Aegean Islands, 1, pp. 78-84, Edinburgh at the University Press, Edinburgh, 1965.

2. Guner A, Aslan S, Ekim T, Vural M, Babac MT, A checklist of the Flora of Turkey (vascular plants), Ed(s), Flora Series 1, 12-14, Nezahat Gökyiğit Botanik Bahçesi Yayınları, 2012.

3. Hayta S, Bagci E. Essential oil constituents of the leaves, bark and cones of Juniperus oxycedrus subsp oxycedrus L. from Turkey. Acta Botanica Gallica: Botany Lett 161(2), 201-207, 2014.

4. Nadia A, Abderrahmane R, Mohamed A, Adams PR. Chemical studies of leaf essential oils of three species of Juniperus From Tensift Al Haouz-Marrakech Region (Morocco). J Essent Oil Res 21(4), 337-341, 2009.

5. Dob T, Dahmane D, Chelghoum C. Essential oil composition of Juniperus oxycedrus growing in Algeria. Pharm Biol 44(1), 1-6, 2006.

6. Elhoussine D, Rachida C. Identification of the volatile constituents of the essential oil of Juniperus oxycedrus L. (Cupressaceae) from the
North Centre Region of Morocco. Asian J Pharm Clin Res, Suppl. 1, 2011.

7. Giuseppa V, Bice B, Filippo M, Aurelio M. The leaf and female cone oils of Juniperus oxycedrus L. subsp. oxycedrus and J. oxycedrus subsp. macrocarpa (Sibth. et Sm.) Ball. from Abruzzo. J Essent Oil Res 15, 418-421, 2003.

8. Medini H, Manongiu B, Aicha N, Chekir-Ghedira L, Harzalla-Skhiri F, Khouja ML. Chemical and antibacterial polymorphism of Juniperus oxycedrus ssp. oxycedrus and Juniperus oxycedrus ssp. macrocarpa (Cupressaceae) leaf essential oils from Tunisia. J Chem 2013, 1-9, 2013.

9. Adams RP. The leaf essential oils and chemotaxonomy of Juniperus sect. Juniperus. Biochem System Ecol 26, 637-645, 1998.

10. Yazid FC, Noureddine Y. Enantiomeric and non-enantiomeric monoterpenes of Juniperus communis L. and Juniperus oxycedrus needles and berries determined by HS-SPME and enantioselective GC/MS. Food Chem 135, 1796-1800, 2012.

11. Koukos PK, Papadopoulous KI, Papagiannopoulos AD. Variation in the chemical composition of the berry oil of Juniperus oxycedrus L. grown in North and West Greece. Eur J Wood Wood Prod 60, 152-153, 2002.

12. Hajdari A, Mustafa B, Gashi V, Nebija D, Ibraliu A, Novak J. Chemical composition of the essential oils of ripe berries of Juniperus oxycedrus L., growing wild in Kosovo. Biochem System Ecol 57, 90-94, 2014.

13. Monica RL, Rosa T, Filomena C, Antoine MS, Giancarlo AS, Francesco M. Comparative chemical composition, antioxidant and hypoglycaemic activities of Juniperus oxycedrus ssp. oxycedrus L. berry and wood oils from Lebanon. Food Chem 105, 572-578, 2007.

14. Monica RL, Antoine MS, Rosa T, Giancarlo AS, Francesco M, Ilaria L, Roberto G, Jindrich C, Hans WD. Phytochemical analysis and in vitro antiviral activities of the essential oils of seven Lebanon species. Chem Biodivers 5, 461-470, 2008.

15. Eduardo GH, Del Carmen R, Rafael GV. Determination by gas chromatography of terpenes in the berries of the species Juniperus oxycedrus L., J. thurifera L., and J. sabina L. J Chromatogr 396, 416420, 1987.

16. Marongiu B, Porcedda S, Caredda A, De Gioannis B, Vargiu L, La Colla $P$. Extraction of Juniperus oxycedrus ssp. oxycedrus essential oil by supercritical carbon dioxide, influence of some process parameters and biological activity. Flavour Fragr J 18(5), 390-397, 2003.

17. Medini H, Ameur E, Khouja ML, Piras A, Porcedda S, Falconieri D, Marongiuc B, Farhat F, Chemli R. Chemical composition of the essential oils of the berries of Juniperus oxycedrus $L$. ssp. rufescens ( $L$. K.) and Juniperus oxycedrus L. ssp. macrocarpa (S. \& m.) Ball. and their antioxidant activities, Nat Prod Res 26(9), 810-820, 2012.

18. Sezik E, Kocakulak E, Baser KHC, Ozek T. Composition of the essential oils of Juniperus oxycedrus subsp. macrocarpa from Turkey. Chem Nat Compound 41(3), 352-354, (2005).

19. Skoula, M., Abbes, J. E., Johnson, C. B. Genetic variation of volatiles and rosmarinic acid in populations of Salvia fruticosa Mill. growing in Crete. Bichem Systemt Ecol 28, 551-561, (2000).

Received : 07.01.2016

Accepted : 26.05.2016 